\title{
Potential immunosuppressive effects of Escherichia coli 0157:H7 experimental infection on the bovine host
}

\author{
E. Kieckens ${ }^{1,3^{*}}$ (D) J. Rybarczyk ${ }^{1,3}$, R. W. Li ${ }^{2}$, D. Vanrompay ${ }^{3+}$ and E. Cox ${ }^{1+}$
}

\begin{abstract}
Background: Enterohaemorrhagic Escherichia coli (EHEC), like E. coli O157:H7 are frequently detected in bovine faecal samples at slaughter. Cattle do not show clinical symptoms upon infection, but for humans the consequences after consuming contaminated beef can be severe. The immune response against EHEC in cattle cannot always clear the infection as persistent colonization and shedding in infected animals over a period of months often occurs. In previous infection trials, we observed a primary immune response after infection which was unable to protect cattle from reinfection. These results may reflect a suppression of certain immune pathways, making cattle more prone to persistent colonization after re-infection. To test this, RNA-Seq was used for transcriptome analysis of recto-anal junction tissue and ileal Peyer's patches in nine Holstein-Friesian calves in response to a primary and secondary Escherichia coli O157: H7 infection with the Shiga toxin (Stx) negative NCTC12900 strain. Non-infected calves served as controls.

Results: In tissue of the recto-anal junction, only 15 genes were found to be significantly affected by a first infection compared to 1159 genes in the ileal Peyer's patches. Whereas, re-infection significantly changed the expression of 10 and 17 genes in the recto-anal junction tissue and the Peyer's patches, respectively. A significant downregulation of 69 immunostimulatory genes and a significant upregulation of seven immune suppressing genes was observed.

Conclusions: Although the recto-anal junction is a major site of colonization, this area does not seem to be modulated upon infection to the same extent as ileal Peyer's patches as the changes in gene expression were remarkably higher in the ileal Peyer's patches than in the recto-anal junction during a primary but not a secondary infection. We can conclude that the main effect on the transcriptome was immunosuppression by E. coli O157:H7 (Stx ${ }^{-}$) due to an upregulation of immune suppressive effects (7/12 genes) or a downregulation of immunostimulatory effects (69/94 genes) in the ileal Peyer's patches. These data might indicate that a primary infection promotes a re-infection with EHEC by suppressing the immune function.
\end{abstract}

Keywords: RNA-Seq, Escherichia coli O157:H7, Cattle, Immunosuppression

\section{Background}

Enterohaemorrhagic Escherichia coli (EHEC), such as E. coli $\mathrm{O} 157: \mathrm{H} 7$, are frequently detected in faecal cattle samples at slaughter (6.3\% in Belgium, $n=1281)$ [1]. Cattle are the main natural reservoir, do not show clinical signs upon infection and can remain asymptomatic

\footnotetext{
* Correspondence: evelien.kieckens@ugent.be

${ }^{\dagger}$ Equal contributors

'Laboratory of Immunology, Faculty of Veterinary Medicine, Ghent University, Salisburylaan 133, 9820 Merelbeke, Belgium

${ }^{3}$ Laboratory of Immunology and Animal Biotechnology, Faculty of Bioscience Engineering, Ghent University, Coupure Links 653, 9000 Ghent, Belgium Full list of author information is available at the end of the article
}

carriers for a very long period. If humans become infected by consuming contaminated food, mainly inadequately cooked beef products, the consequences can be severe [2]. After ingestion and subsequent colonization of the human colon, EHEC releases Shiga toxins causing microvascular endothelial injuries, which might lead to bloody or non-bloody diarrhea, haemorrhagic colitis and the haemolytic uremic syndrome [3, 4].

Recently, the prevalence of EHEC was studied in 12 Belgian cattle herds of which some animals were diagnosed as EHEC-positive at slaughter [5]. Longitudinal follow up of herds showed that faecal samples were intermittent positive, while some animals were suggested 
to have a chronic excretion over a period of at least 612 weeks was observed. Of the intermittent shedders, one animal was positive at the beginning of the study and was also excreting when sampled 11 months later. Furthermore, the shedding patterns showed that positive animals can shed different strains at different sample points [6]. Other studies showed that positive animals became culture negative within $2-3$ months after the first testing [7]. The immune response of the animals against the EHEC strains, which has been investigated in few studies, might explain these excretion patterns. One study demonstrated that antibodies against the O157 lipopolysaccharide (LPS) and Shiga toxin-1 and -2 (Stx1, Stx2) frequently occur in bovine sera and colostrum upon experimental infection [8], but this response could not clear the infection, as infected animals secreted bacteria over a period of months [4]. Another study on two farms demonstrated that faecal excretion was not always correlated with $E$. coli secreted protein A (EspA), intimin and, translocated intimin receptor (Tir) specific serum antibody responses. In contrast, $87.5 \%$ of the animals showed a serum antibody response against Escherichia coli secreted protein $\mathrm{B}(\mathrm{EspB})$ at the same time that their faecal sample was positive for EHEC O157, O26 or, O111 or 6 weeks after a positive faecal sample. These antibodies persisted, even when shedding had ceased, until the animals were slaughtered, which was 2-8 months later, whereas EspA-specific antibodies disappeared within 2 months [9]. These results indicate that farm animals, which develop an immune response after infection, can become reinfected by different EHEC strains as evidenced by intermittent excretion which may reflect suppression of certain pathways of the immune system by the primary infection, making cattle more prone to persistent colonization by a subsequent infection.

In 2003, Naylor et al. [10] described the preference of $E$. coli $\mathrm{O} 157: \mathrm{H} 7$ for the terminal rectum up to the recto-anal junction (RAJ) as primary site for colonization. This site is characterized by a high density of lymphoid follicles. Predilection for epithelium above mucosa-associated tissue could be important for modulating the immune system. Indeed, EHEC O157 is capable of suppressing cellmediated immune responses in cattle by targeting lymphocytes via their Shiga toxins $[8,11]$, but enterocytes do not have receptors for these toxins, suggesting that close contact with the immune system might be necessary. Here, the ileal Peyer's patches might play a role as they are of major importance for the mucosal immune responses in cattle [12]. In this study, a Stx negative strain was used for biosafety reasons. Nevertheless immunomodulating effects of other virulence factors of $E$. coli $\mathrm{O} 157: \mathrm{H} 7$ have been described. The H7 flagellin, bacterial LPS and type IV pilus have been shown to induce proinflammatory responses upon EHEC infection. On the contrary, it has been observed that EHEC as wells as EPEC strains could suppress NF- $\mathrm{KB}$ and MAPK activation as well as ІкB degradation, [13] and could inhibit the production of proinflammatory cytokines IL-8 and IL-6, early in the infection by different LEE- and non-LEE encoded effectors (Tir, NleB, NleC, NleD, NleE, NleH1 and NleH2) [14]. Clearance of EHEC O157 is associated with an upregulation of Th-1 associated transcripts within the rectal mucosa, the principle site of colonization $[10,15]$, suggesting that a cellular component of the adaptive immune response may be important in EHEC O157 control.

In this study we wanted to obtain insights in genes involved in an immunosuppressive effect of an E. coli O157:H7 Stx negative strain. In our experimental infections prolonged excretion was observed after a second infection with this strain. Transcriptome analysis of the ileal Peyer's patches and the RAJ from calves was performed using RNA-seq technology. Samples were taken from animals infected either once or twice which have never been in contact with $E$. coli $\mathrm{O} 157: \mathrm{H} 7$.

\section{Methods \\ Bacterial strain}

The E. coli O157:H7 strain NCTC 12900, a wellcharacterized Shiga-toxin negative E. coli $\mathrm{O} 157: \mathrm{H} 7$ strain of human origin with naladixic acid resistance [16] was used for experimental infections in calves. We used this Stx-negative strain for biosafety reasons. Bacteria were grown overnight in Luria Bertani broth (LB) with aeration (200 rpm) at $37{ }^{\circ} \mathrm{C}$, harvested by centrifugation $(11337 \times$ $\mathrm{g}, 5 \mathrm{~min}$ ), re-suspended in sterile phosphate-buffered saline (PBS) to a concentration of $10^{10} \mathrm{CFU} / 10 \mathrm{ml}$ and subsequently used for experimental infections.

\section{Experimental infection of calves and sample collection}

Nine 5-week-old Holstein-Friesian calves were randomly assigned to three groups (primary infection, re-infection and uninfected control; $n=3$ ), each reared in separate boxes in isolation units (Fig. 1). These animals were screened to be seronegative for intimin, EspA and EspB, as well negative for faecal shedding of $E$. coli $\mathrm{O} 157: \mathrm{H} 7$ and non-O157:H7. The animals were milk-fed from their arrival until the end of the experiment and allowed free access to hay, water and grain-based pellets. The milkuptake gradually decreased as the animals were able to digest more pellets, to allow a normal development of the gastro-intestinal tract.

Six animals were inoculated at the age of 6 weeks with $10^{10} \mathrm{CFU}$ during two consecutive days as previously described by Kieckens et al. [17]. Two weeks after infection, three animals were euthanized (Infection Group, IG). At the same time, the remaining three infected animals were re-infected and euthanized 2 weeks later at 10 weeks of age (Re-infection Group, RG). At that time, the 


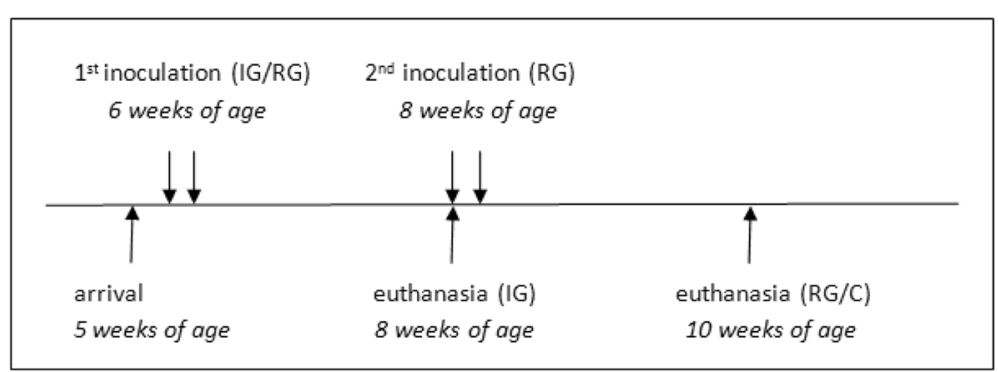

Fig. 1 Experimental setup

three uninfected control animals (Control Group, C) of the same breed and age, were also euthanized (Fig. 1). Euthanasia was carried out by captive bolt and samples from the ileal Peyers' patches and the RAJ were collected for RNA isolation to analyze the transcriptome profiles by RNA-Seq. Hereto, tissue samples of $1 \mathrm{~cm}^{2}$ were cut and rinsed in sterile cold PBS $\left(4{ }^{\circ} \mathrm{C}\right)$ and immediately frozen in liquid nitrogen and stored at $-80{ }^{\circ} \mathrm{C}$ until RNA purification. All experimental and animal management procedures were undertaken in accordance to the requirements of the animal care and ethics committee of the Faculty of Veterinary Medicine, Ghent University, Belgium (EC2011/082).

\section{Excretion of E. coli 0157:H7}

Faecal samples were analyzed immediately after sampling, as described by Vande Walle et al. [18]. Briefly, ten gram of faeces was homogenized in $90 \mathrm{ml}$ sterile modified tryptone soy broth (Oxoid Ltd., Hanst, United Kingdom) supplemented with $20 \mathrm{mg} / \mathrm{liter}$ novobiocin (Sigma Aldrich, St. Louis, MO, USA). Enumeration of $E$. coli $\mathrm{O} 157$ was performed by plating 10-fold serial dilutions onto MacConkey agar supplemented with sorbitol, cefixime, tellurite and nalidixic acid (NalCT-SMAC) (Merck, Darmstadt, Germany) and incubating the plates at $37^{\circ} \mathrm{C}$ for $18 \mathrm{~h}$. The remaining broth was enriched for $6 \mathrm{~h}$ at $42{ }^{\circ} \mathrm{C}$ and subjected to immunomagnetic separation (IMS) using Dynabeads (Invitrogen, Merelbeke, Belgium), according to the manufacturer's instructions. Finally, $100 \mu \mathrm{l}$ was plated onto NalCT-SMAC agar and incubated for $18 \mathrm{~h}$ at $37{ }^{\circ} \mathrm{C}$. Selected sorbitol-negative colonies were confirmed by the O157-specific latex agglutination assay (Oxoid Ltd., Basingstoke, United Kingdom).

\section{RNA extraction and sequencing using RNA-seq}

Total RNA was extracted from the tissues using the Qiagen RNeasy mini kit as described by the manufacturer. Briefly, the samples were ground to a fine powder under liquid nitrogen using a mortar and pestle and homogenized. Then, the lysate was further processed as instructed by Qiagen. The RNA purity was verified using
NanoDrop Technology (Thermo Fisher Scientific, USA) and the RNA concentration was measured. High-quality RNA $(260 / 280 \mathrm{~nm}$ ratio $\sim 2.0$; RNA Rin\# > 8.0) was processed using an Illumina TruSeq RNA sample prep kit following manufacturer's instruction (Illumina, San Diego, CA, USA). Individual RNA-Seq libraries were pooled based on their respective sample-specific 6-bp adaptors and sequenced at $50 \mathrm{bp} /$ sequence read using an Illumina HiSeq2000 sequencer.

\section{Data analysis and bioinformatics}

The mean number of raw reads generated per sample in the study was $18,910,480.56 \pm 5,610,677.59$ (mean \pm SD; $n=18$ ). SolexaQA was used for trimming and filtering using default parameters. The resultant reads with $<40 \mathrm{bp}$ in length were discarded. After performing trimming and filtering, the final number of reads for the genome alignment was $16,042,336.72 \pm 5,046,779.84$ (mean $\pm \mathrm{SD})$.

The resultant quality reads were aligned to the bovine reference genome (UMD 3.1) using TopHat2 (v2.0.6) [19] using the following parameters: mismatches allowed: $2 \mathrm{bp}$; and max insertions: 3 bp and max deletions: 3 bp (using bowtie2 v2.0.2 with INDEL allowed). The SAM output files from the TopHat alignment, along with the GTF file from ENSEMBL bovine genebuild v67.0, were used in the Cuffdiff program in the Cufflink package (v2.0.2) to test for differential gene expression. Mapped reads were normalized based on the upper-quartile normalization method. Cuffdiff models the variance in fragment counts across replicates using the negative binomial distribution [20].

Results were considered significant for $p<0.05$. Differentially expressed genes identified in the transcriptome were further analyzed using GeneOntology (GO) analysis (https://github.com/tanghaibao/goatools) after FDR correction for FDR $<0.1$. A Fisher 's exact test was used for enrichment of certain GO terms. A multiple correction control (permutation to control false discovery rate, FDR) was implemented to set up the threshold to obtain the list of significantly over-represented GO-terms as previously described [21]. 
IPA (Ingenuity Pathway Analysis) and Path designer was used to visualize connections between differentially expressed genes.

The fold change was reported in the result section for every gene in brackets.

\section{Results}

\section{Excretion of E. coli 0157:H7 (Stx ${ }^{-}$)}

Average excretion patterns of the infected animals are shown in (Fig. 2).Animals were negative before infection and the highest peak of bacteria in faeces was detected at day 4 post infection. Within 14 days after the primary infection, all animals of the primary infection group became negative. The second infection gave rise to a lower level of bacterial shedding but these animals were still shedding bacteria at euthanasia.

\section{Transcriptome analysis of gut tissues}

A total of 21,046 genes were detected at least once in one of the nine RAJ samples or in one of the nine ileal Peyer's patches samples. The number of genes expressed per sample was $18,753.22 \pm 276.94$ (Mean \pm SD). The number of genes with mean hits $\geq 5.0$ was 16,788 whereas the core transcriptome of the RAJ and the ileal Peyer's patches consisted of 16,948 and 17,197 genes, respectively. This core transcriptome incorporates genes represented by at least one sequence hit in each of the samples tested.

We used the transcript abundance classification as described by Li et al. [21]. Assuming 300,000 mRNA molecules per cell, approximately $70.68 \%$ of genes transcribed in the RAJ and $70.55 \%$ of genes transcribed in the ileal Peyer's patches can be classified into "very rare" with a relative abundance of $\leq 15$ molecules per cell (Table 1 ), followed by "rare" (16-99 molecules per cell) at 16.18 and $17.29 \%$, respectively. "Not expressed" genes ( 0 molecules per cell) were calculated as 11.17 and $10.18 \%$, whereas "moderately abundant" genes (100-500 molecules per cell) accounted for 1.74 and $1.78 \%$. "Abundant" genes were only for 0.23 and $0.21 \%$ part of the transcriptome.

\section{Genes significantly influenced by $E$. coli $0157: \mathrm{H} 7$ experimental infections}

In the RAJ, the primary site of E. coli O157:H7 colonization in cattle, fifteen genes were found to be significantly affected by a primary infection with $E$. coli O157:H7 whereas ten genes were affected after re-infection compared to the uninfected control group (false discovery rate $F D R<0.1$ ). Only one gene $(F A B P 2)$ appeared to be significantly impacted by both primary infection and re-infection with $E$. coli O157:H7 (Fig. 3). Three out of fifteen genes that were significantly affected during the primary infection could be linked to an immune function (KLRJ1, $M A R C O, C C L 20) ;$ one was upregulated and two downregulated (Table 2). In the ileal Peyer's patches 1159 genes were significantly influenced by a primary infection compared to the control group and only seventeen genes were significantly affected by the reinfection compared to the same control, indicating a larger effect on the transcriptome during primary infection compared to a re-infection. Seven genes were significantly different regulated after a primary as well as after a re-infection (Fig. 4). The function of 103 out of 1159 genes that were differently regulated

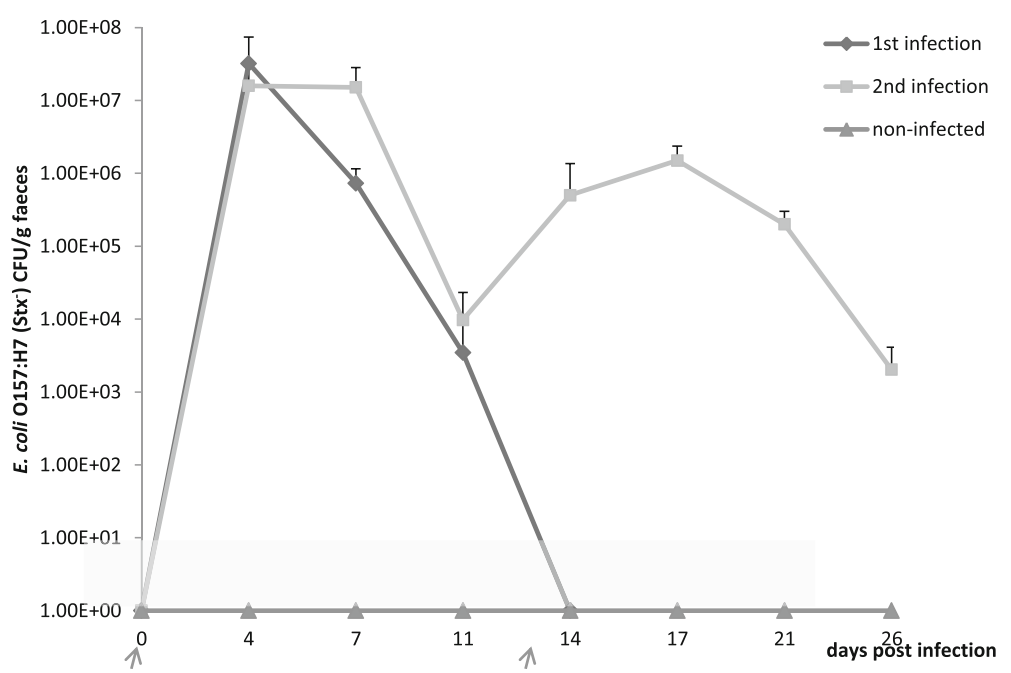

Fig. 2 Average faecal excretion of infected animals. Error bars indicate standard deviations. Arrows on the x-axis indicate the timepoint of first and second infection 
Table 1 Transcript abundance in the recto-anal junction and lleal Peyer's patches

\begin{tabular}{lll}
\hline Transcript category & Recto-anal junction & Ileal Peyer's patches \\
\hline Not expressed & $11.17 \%$ & $10.18 \%$ \\
Very rare & $70.68 \%$ & $70.55 \%$ \\
Rare & $16.18 \%$ & $17.29 \%$ \\
Moderately abundant & $1.74 \%$ & $1.78 \%$ \\
Abundant & $0.23 \%$ & $0.21 \%$ \\
\hline
\end{tabular}

during the primary infection could be traced back to the immune system.

\section{Gene ontology (GO) analysis}

A total of 15 genes were significantly affected by a primary infection with EHEC in the RAJ at a cutoff FDR $<10 \%$. Enrichment with Bonferroni corrected $P$ value $=$ 0.0115 reveals three genes possessing scavenger receptor activity (GO:0005044) and three genes having cargo receptor activity (GO:0038024). In the Peyer's patches ileum, 1159 genes were significantly affected by a primary EHEC infection. After enrichment, we could identify 997 genes linked to a molecular function (GO:0003674), 882 genes to biological processes (GO:0008150), 673 genes were linked to a cellular process (GO:0009987) and 561 genes to a single-organism process (GO:0044699). Also GOterms for metabolic process (GO:0008152), singleorganism cellular process (GO:0044763), catalytic activity (GO:0003824), response to stimulus (GO:0050896), cellular response to stimulus (GO:0051716), nitrogen compound metabolic process (GO:0006807), single-organism metabolic process (GO:0044710), hydrolase activity (GO:0 016787), small molecule metabolic process (GO:0044281), and response to stress (GO:0006950) were found for 492, 488, 405, 329, 247, 230, 223, 204, 145 and 123 genes, respectively, out of 1159 genes that were significantly impacted. GO-terms for $<100$ genes were not reported in this manuscript.

\section{Regulatory gene networks}

The IPA software was used to further examine the RNASeq dataset. Uploading the dataset for the RAJ after a primary infection, the database could assign two relationships between the significantly regulated genes, whereas for the re-infection four relationships could be detected in both cases linked to antimicrobial responses. When the data for ileal Peyer's patches was uploaded, IPA could identify three different networks that might play a role in EHEC infection, related to antimicrobial response (28 relationships) (Fig. 5), inflammatory response (69 relationships) (Fig. 6) and infectious disease (166 relationships) (Fig. 7).

\section{Possible effect of E. coli 0157:H7 experimental infection on the function of immune cells}

In order to gain insight in the impact of the differential mRNA expression, the data were arranged according to their effect on different immune cells in the specific tissues: lymphocytes (3.5.1), natural killer cells (3.5.2), monocytes and macrophages (3.5.3), dendritic cells (3.5.4), granulocytes (3.5.5) Only genes with the highest fold changes per cell type are reported. The gene expression results for RAJ and ileal Peyer's patches after primary infection are represented in Tables 3 and 4, respectively.

\section{Lymphocytes}

In the RAJ, a significant downregulation of Chemokine $C$-C motif ligand 20 (CCL20) (fold change $=0.07$ ) was observed, which is strongly chemotactic for immature dendritic cells, and B- and T-lymphocytes [22].

Furthermore, in the ileal Peyer's patches, Sushi domain containing 2 (SUSD2) was significantly upregulated (fold

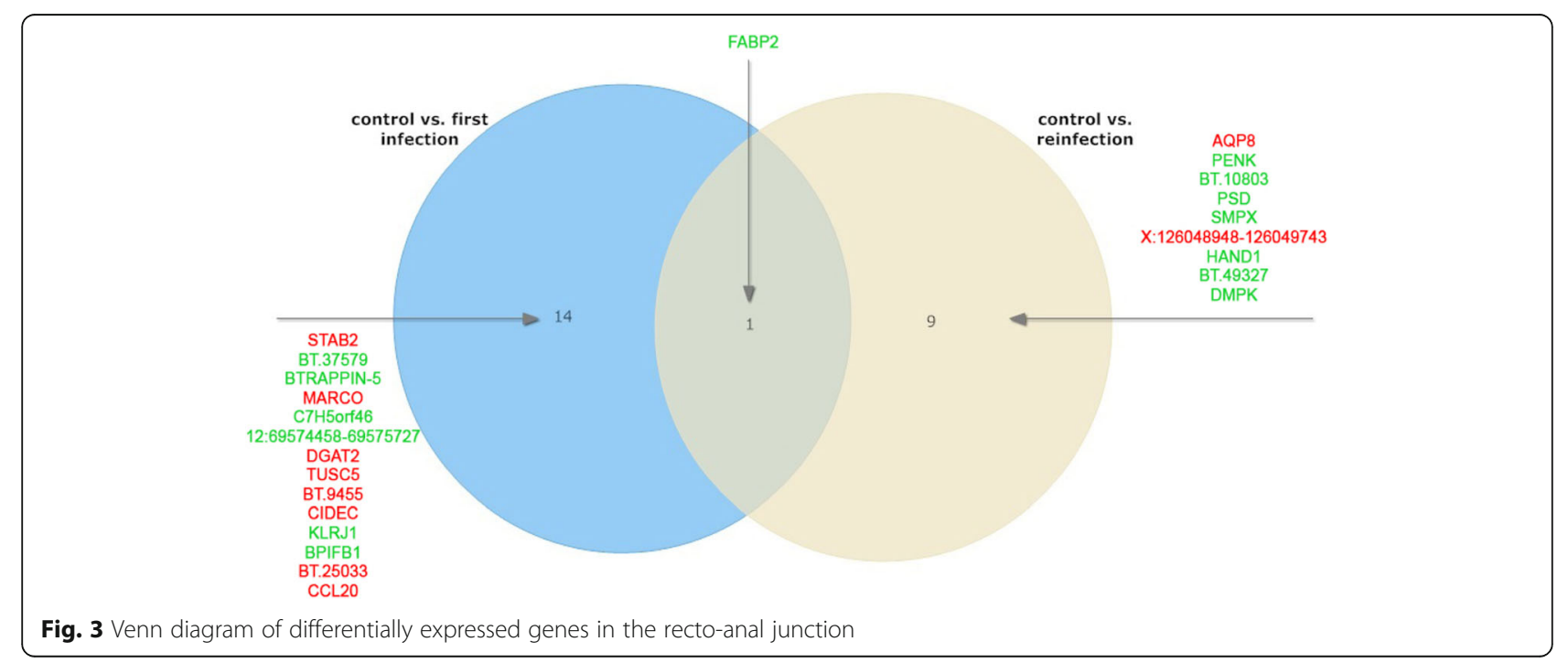


Table 2 Overview of numbers of up- and downregulated genes in respect to their effect on the immune system

\begin{tabular}{|c|c|c|c|c|}
\hline \multicolumn{3}{|c|}{ Immune stimulating effect } & \multicolumn{2}{|c|}{ Immune suppressive effect } \\
\hline & \# upregulated & \# downregulated & \# upregulated & \# downregulated \\
\hline Recto-anal junction & / & 2 & 1 & / \\
\hline lleum + PP & 25 & 67 & 6 & 5 \\
\hline
\end{tabular}

change = 4.75). SUSD2 can interact with Galectin-1 which is known to contribute to the evasion of immune responses of tumors and infectious organisms by inducing apoptosis of activated $\mathrm{T}$ cells [23]. The activation of $\mathrm{T}$ lymphocytes might be inhibited by the significant downregulation of the expression of $T$ cell immunoglobulin and mucin domain 4 (TIMD4) (fold change $=0.20$ ), responsible for regulation of Th1 responses [24]. C-X-C motif ligand 13 chemokine (CXCL13), strongly expressed in the follicles of the spleen, lymph nodes and Peyer's patches promoting the migration of $\mathrm{B}$ lymphocytes in the lymph nodes [25] was significantly downregulated in the ileum (fold change $=0.01$ ). Interleukin 17 receptor E-like (IL17REL), a member of the Interleukin 17 (IL17) cytokine receptor family that functions as a receptor for the proinflammatory cytokine responding to invading extracellular pathogens [26] was found to be significantly downregulated (fold change $=0.29$ ) upon E. coli $\mathrm{O} 157: \mathrm{H} 7$ infection. A significant downregulation of prothymosin alpha (PTMA), a tumor necrosis factor receptor (RELT), Interleukin-21 receptor (IL21R), a guanine nucleotide exchange factor $(V A V 1)$ with fold change $=0.41,0.38,0.36$,
0.35 respectively and many more immune response stimulating genes linked with lymphocyte responses were seen in the ileal Peyer's patches.

\section{Natural Killer (NK) cells}

Effector functions of NK cells are controlled by a balance of inhibitory and stimulatory signals. In the RAJ, a strong significant upregulation of killer cell lectin-like receptor (KLRJ1) was observed (fold change=14.93). KLRJ1 is probably important for the NK cell recognition of target cells, which are certain tumor cells, virally infected cells and host MHC class I cells as a mechanism of self/health recognition. An upregulation of KLRJ1 would imply an upregulation of the inhibitory signal, causing more survival of the target cells [27]. In the ileal Peyer's patches, a significant upregulation of protein disulfide isomerase (PDIA2) (fold change $=21.28$ ), killer cell immunoglobulin-like receptor, two domains, short cytoplasmic tail 1 (KIR2DS1) (fold change $=7.61)$, killer cell immunoglobulin-like receptor, two domains, long cytoplasmic tail 5A (KIR2DL5A) (fold change $=3.52$ ) and killer cell lectin-like receptor subfamily $C$, member 1-like

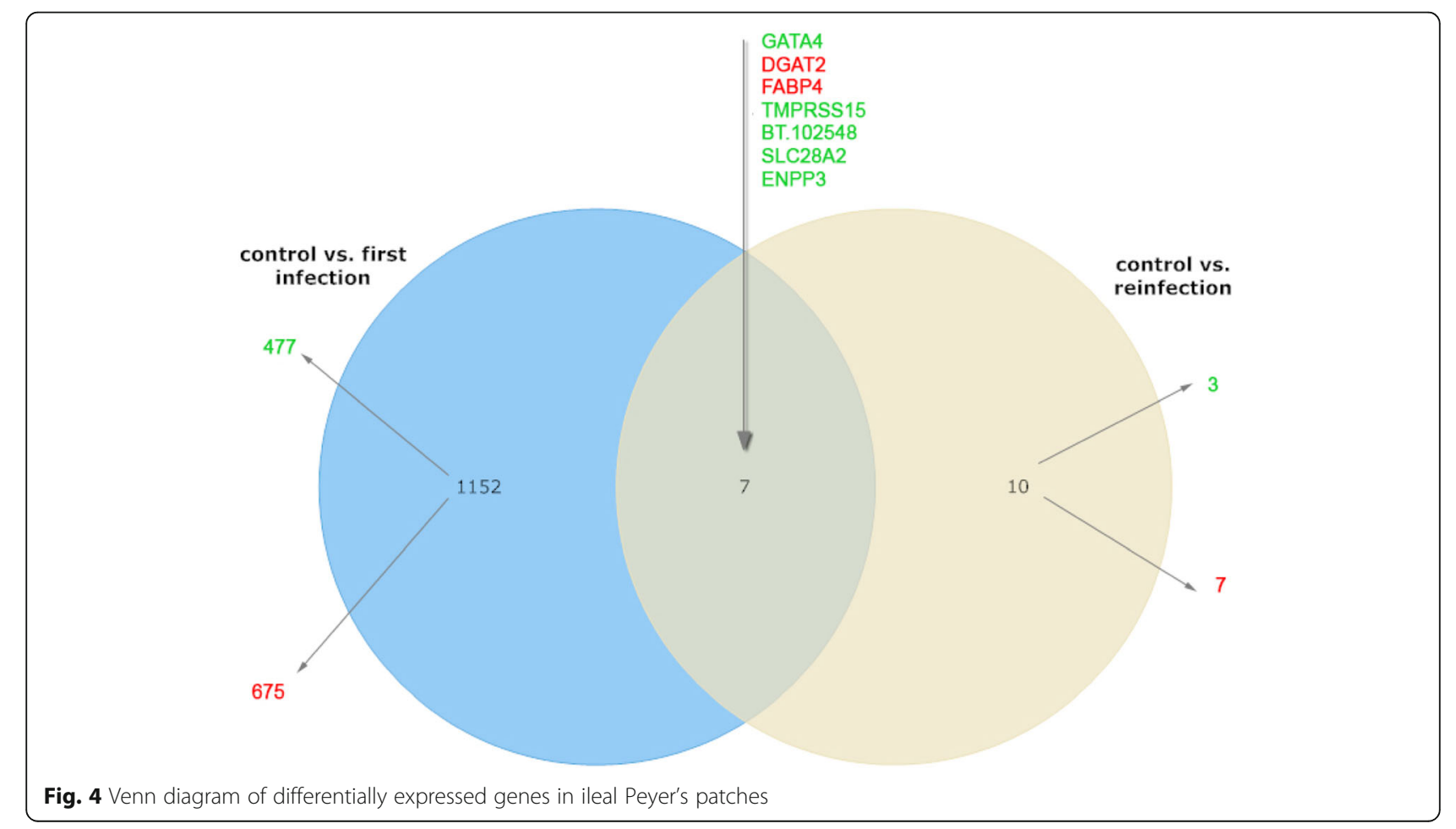




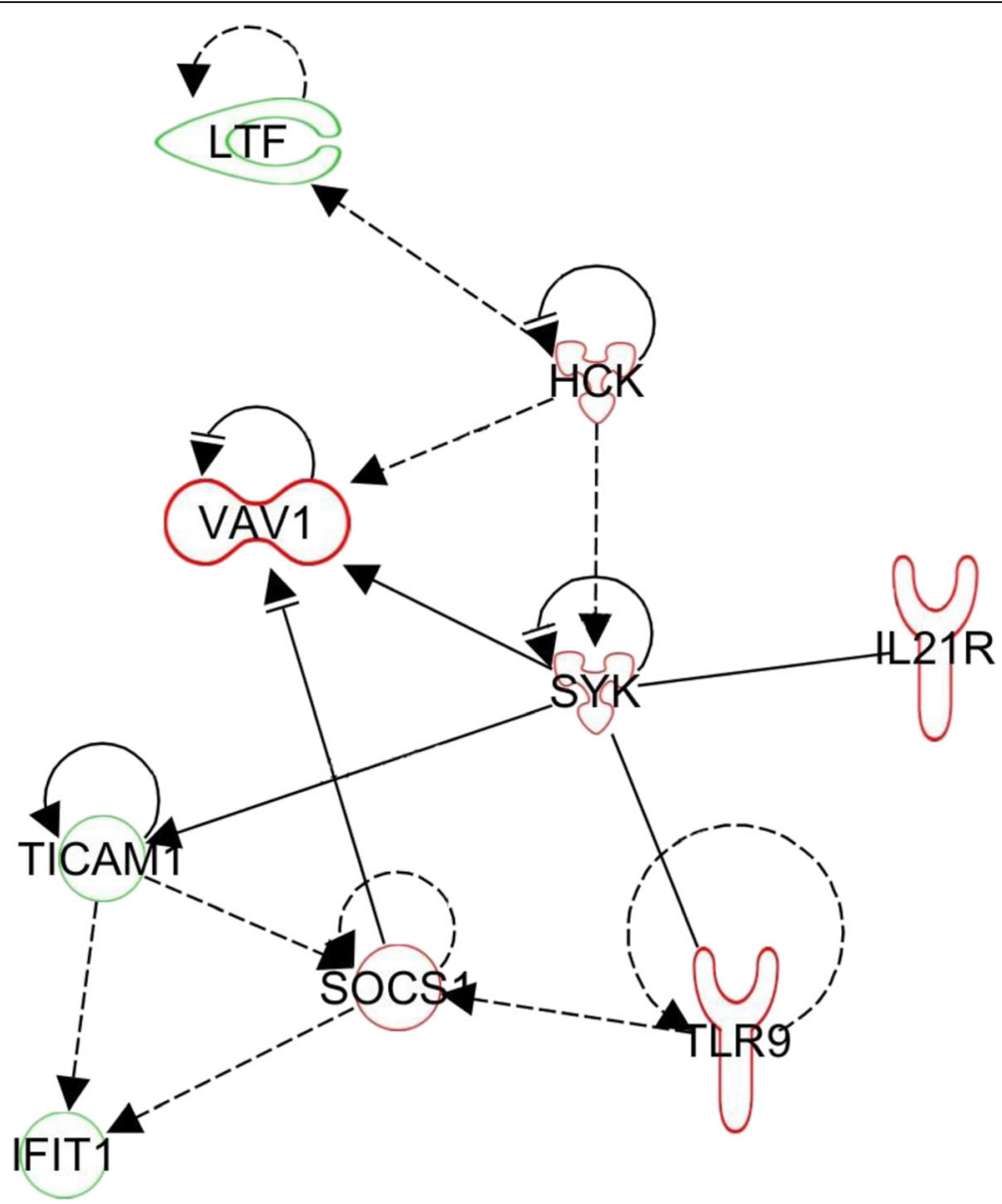

Fig. 5 Regulatory network related to antimicrobial response impacted in the ileal Peyer's patches of calves after a primary infection with $E$. coli 0157:H7. Up- and downregulation is represented by green and red colours, respectively

(KLRC1) (fold change $=2.58$ ) was observed. In contrast, a significant downregulation of $I L 21 R$ (fold change $=0.36$ ) important for the proliferation and differentiation of B-, T- and NK cells, leukocyte-associated immunoglobulinlike receptor 1 (LAIR1) (fold change $=0.29$ ) an inhibitory receptor found on NK cells, T cells and B cells regulating the immune response to prevent lysis of cells recognized as self [28], hematopoietic cell signal transducer (HCST) (fold change $=0.24$ ) playing a role in cell survival and proliferation by activation of NK and $\mathrm{T}$ cell responses $[29,30]$ and killer cell lectin-like receptor subfamily $F$, member 1 (KLRF1) (fold change =0.12) stimulating the cytotoxicity and cytokine release of NK cells [31], was observed.

\section{Monocytes and macrophages}

In the RAJ, macrophage receptor with collagenous structure $(M A R C O)$ was significantly downregulated (fold change = 9.20). This is a receptor which is part of the innate antimicrobial immune system binding both Gram-negative and Gram-positive bacteria via an extracellular, C-terminal, scavenger receptor cysteine-rich (SRCR) domain [32].

At the ileal Peyer's patches significant upregulation was seen of ectonucleotide pyrophosphatase/phosphodiesterase 7 (ENPP7), PDIA2, carboxypeptidase M (CPM) important for monocyte to macrophage differentiation [33], the inflammatory purinergic receptor ligand-gated ion channel, 7 (P2RX7) and egf-like module containing, mucin-like, hormone receptor-like 4 pseudogene (EMR4P), a member of the EGF-TM7 receptor gene family which is thought to be important for adhesion and migration of macrophages [34] with fold changes of 974.24, 21.28, 3.33, 3.24 and 2.64, respectively. Al these genes result in stimulation of the immune system on level of monocytes and macrophages. On the other hand, macrophage migration inhibitory factor (MIF) which is important for the acute immune response [35] was significantly downregulated as well as chemokine $C$-C motif receptor 1 (CCR1) playing a role in recruitment of leukocytes to the effector site [36] (fold change $=0.45$ and 0.36, respectively). Furthermore, sialic acid binding Ig-like lectin 10 (SIGLEC10) which is a 


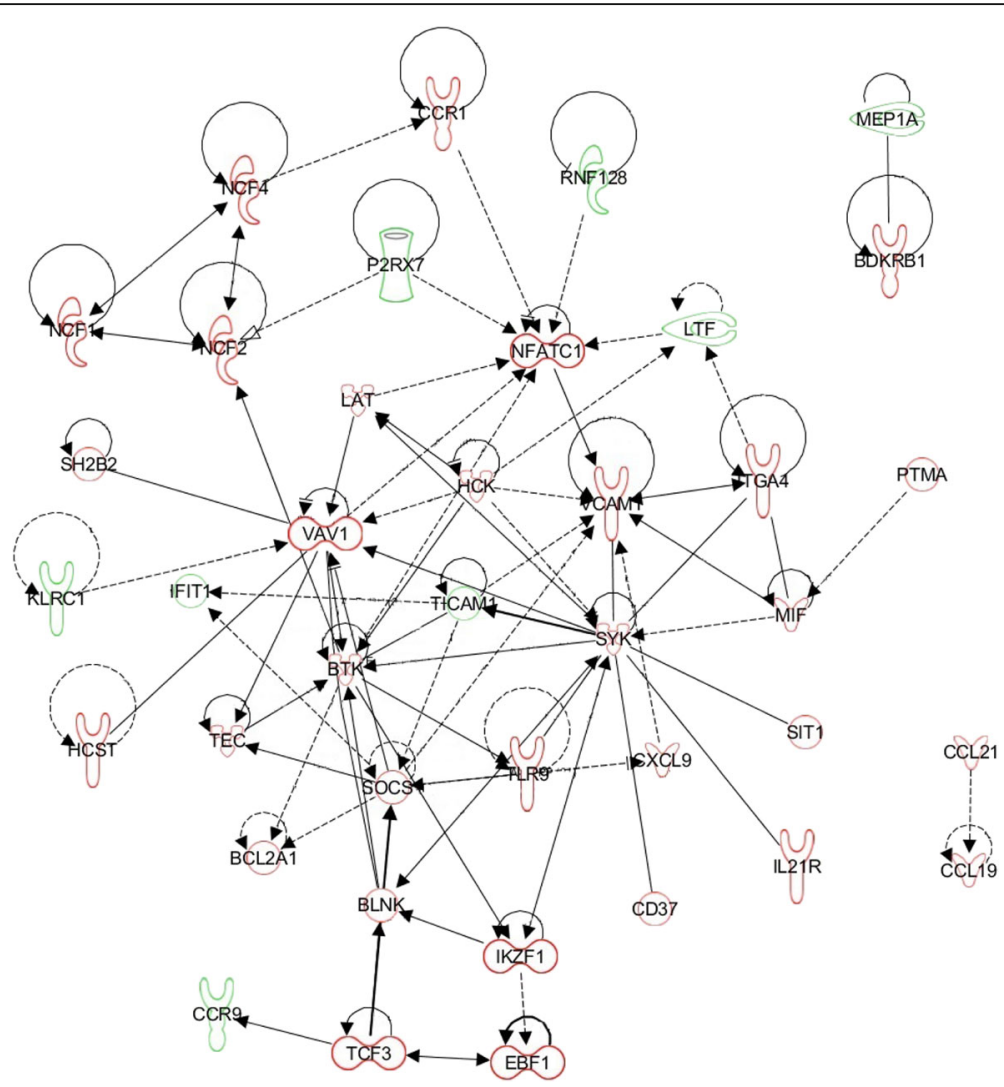

Fig. 6 Regulatory network related to inflammatory response impacted in the ileal Peyer's patches of calves after a primary infection with E. coli 0157:H7. Up- and downregulation is represented by green and red colours, respectively

negative regulator of immune signaling by functioning as an inhibitory receptor [37] and B cell linker (BLNK), an adaptor molecule linked to the pathway activated by Bcell antigen receptor signals [38], were significantly downregulated, with fold changes of 0.01 and 0.26 , respectively.

\section{Dendritic cells (DC's)}

No differential mRNA expression of genes indicating an effect on DC's was seen in the RAJ. In samples from the ileal Peyer's patches, a significant upregulation of PDIA2, toll-like receptor adaptor molecule 1 (TICAM1) (fold change $=2.97$ ) and EMR4P was observed, whereas SIGLEC10 and MIF were significantly downregulated.

\section{Granulocytes}

In the RAJ, there was no differential regulation observed that could have a direct influence on granulocytes. However, in the ileal Peyer's patches, a significant upregulation of ENPP7, PDIA2, chemokine C-C motif ligand 24 (CCL24) (fold change $=3.82$ ), which is chemotactic for eosinophils and neutrophils [39] and of EMR4P was detected. While a significant downregulation of neutrophil cytosolic factor 1 (NCF1) (fold change = 0.31), neutrophil cytosolic factor 2 (NCF2) (fold change $=0.31$ ) and neutrophil cytosolic factor 4 (NCF4) (fold change $=0.43$ ) important for the formation of the neutrophil phagosome leading to phagocytosis of bacteria [40], CCR1, hemopoietic cell kinase $(H C K)$ (fold change $=0.31$ ) playing a role in the neutrophil migration and degranulation [41], SIGLEC10 and vascular cell adhesion molecule 1 (VCAM1) (fold change $=0.88$ ) mediating the adhesion of lymphocytes, monocytes, eosinophils and basophils to vascular endothelium [42], was noticed.

\section{Discussion}

It is well known that some pathogens have developed mechanisms to prolong their persistence in a host and can modulate the host immune response in different ways in order to increase their survival in the host [43]. This might be done by passive evasion of the immune surveillance for instance by altering expressed antigens, as Streptococcus pneumonia does. Another way to survive is actively modulating and interfering with regulatore networks that are part of the immune defence. This is done when EHEC and EPEC inject modulatory proteins into the host cell using T3SS [43-45]. Furthermore, the suppression of immune responses via TLR4 by uropathogenic E. coli (UPEC) leads to a decrease of IL-6 


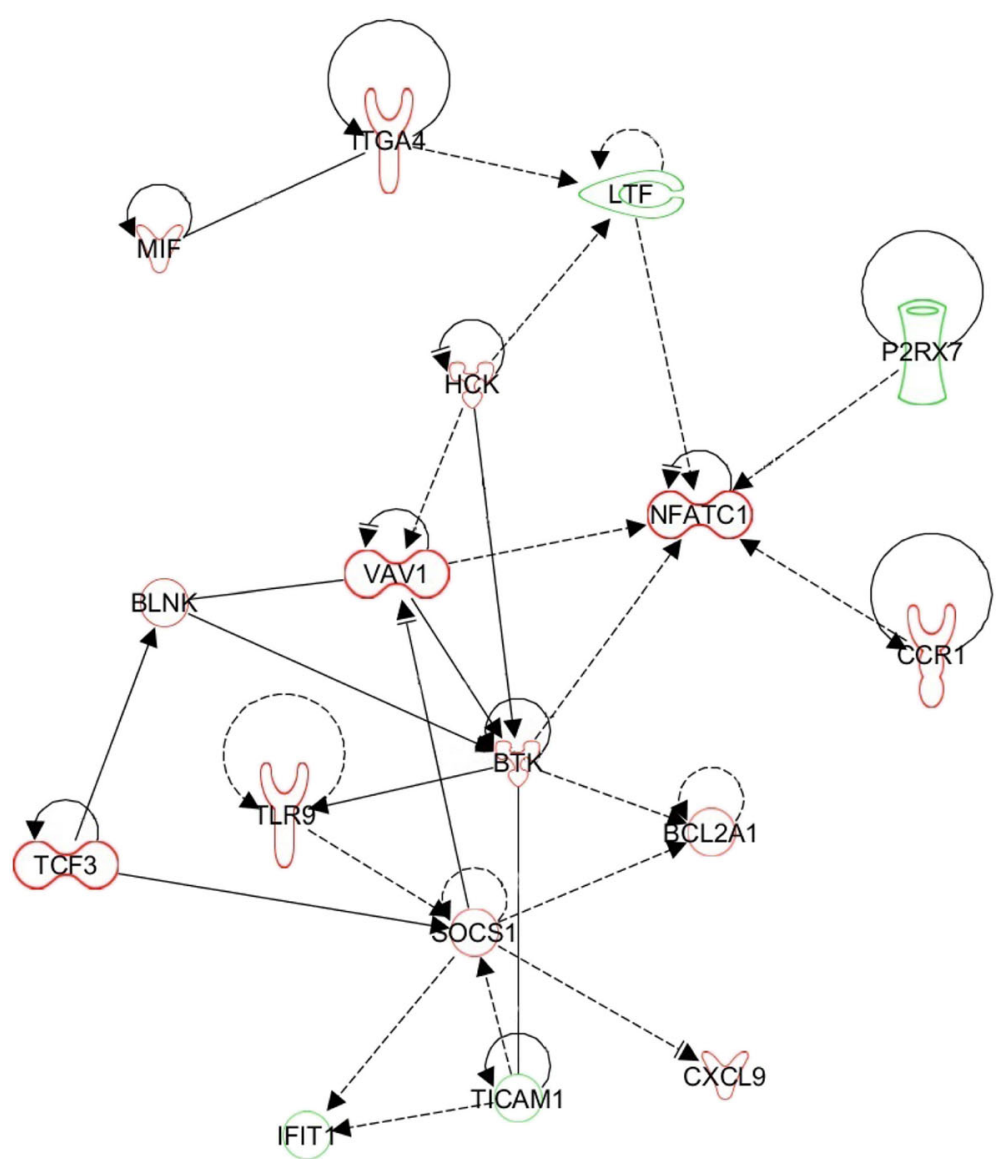

Fig. 7 Regulatory network related to infectious disease impacted in the ileal Peyer's patches of calves after a primary infection with E. coli 0157:H7. Up- and downregulation is represented by green and red colours, respectively

and IL-8 release [46]. This is congruent with our observations in several infection experiments: a primary infection could elicit an antibody response, but this primary immune response was unable to protect against an experimental re-infection with the same strain. On the contrary, whereas the primary infection led to faecal shedding during less than 2 weeks $(<14$ days; $n=32)$, a re-infection resulted in excretion for more than 4 weeks ( $>28$ days; $n=21$ ) (Table 5 ; unpublished results).

To our knowledge, this is the first RNA-Seq study highlighting the effect of a primary infection and a reinfection with $E$. coli $\mathrm{O} 157: \mathrm{H} 7$ in cattle, leading to a better understanding of the transient and sometimes recurrent pattern of EHEC infections. In 2007, Li and Hovde described the differential expression of 49 genes in the RAJ after a primary infection with $E$. coli O157:H7 using cDNA microarray [47]. Here, we used the RNA-Seq technique which allowed us to determine effects on both RAJ and ileal Peyer's patches. We could identify an important difference in regulation of the transcriptome after an initial contact with the bacteria: the ileal Peyer's patches were more influenced by the infection compared to the RAJ, which is part of the primary site for colonization in cattle [10]. In this study we

Table 3 Gene expression results for recto-anal junction samples with fold change $>2$

\begin{tabular}{llll}
\hline Gene name $^{a}$ & Gene function & Fold change & Reference \\
\hline KLRJ1 + (Ly49) & $\begin{array}{l}\text { Natural killer cell receptor binding host MHC I as a mechanism of self/health } \\
\text { recognition. Binding of the ligand results in an inhibitory signal to prevent killing } \\
\text { of the target cell. }\end{array}$ & -3.89971 & Storset et al. (2003) [27] \\
MARCO $^{-}$ & $\begin{array}{l}\text { Innate immune defense. Can bind Gram-negative bacteria to stimulate clearing } \\
\text { of the pathogen. }\end{array}$ & 3.68421 & Elomaa et al. (1998) [32] \\
CCL20 $^{-}$ & Strongly chemotactic for lymphocytes and weakly for neutrophils. & 3.33712 & Mohammed et al. (2007) [22]
\end{tabular}

${ }^{\mathrm{a}}{ }^{+}=$upregulated; $^{-}=$downregulated 
Table 4 Gene expression results for lleal Peyer's patches samples with fold change $>2$

\begin{tabular}{|c|c|c|c|}
\hline $\begin{array}{l}\text { Gene } \\
\text { Name }^{a}\end{array}$ & Gene function & $\begin{array}{l}\text { Fold } \\
\text { change }\end{array}$ & Reference \\
\hline ENPP7 $^{+}$ & $\begin{array}{l}\text { Might have an inflammatory effect, as it could degrade and inactivate platelet- } \\
\text { activating factor (PAF). }\end{array}$ & -9.92813 & Wu et al. (2006) [55] \\
\hline $\mathrm{PDIA}^{+}$ & $\begin{array}{l}\text { Helps to load antigenic peptides into MHC I molecules and is therefore important } \\
\text { in antigen recognition and clearing. }\end{array}$ & -4.4116 & LeBrasseur (2006) [56] \\
\hline BT.36112+ & $\begin{array}{l}\text { (KIR) Killer cell immunoglobulin receptor suppresses the cytotoxic activity of NK } \\
\text { cells. }\end{array}$ & -2.92833 & Vilches et al. (2002) [57] \\
\hline 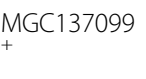 & $\begin{array}{l}\text { Is preferentially expressed on Th2 cells and is together with SEMA4A a stimulatory } \\
\text { molecule for T-cell activation. }\end{array}$ & -2.54481 & $\begin{array}{l}\text { European bioinformatics institute (2015) } \\
\text { [58] }\end{array}$ \\
\hline $\mathrm{PRLR}^{+}$ & $\begin{array}{l}\text { Cytokine receptor and important in the JAK-STAT, JAK-RUSH, Ras-Raf-MAPK and PI- } \\
3 \mathrm{~K} \text { pathways. }\end{array}$ & -2.47279 & $\begin{array}{l}\text { Bouchard et al. (1999) [59], Lee et al. } \\
\text { (1999) [60], Amaral et al. (2004) [61] }\end{array}$ \\
\hline LY6G6E & $\begin{array}{l}\text { Possible role of Ly- } 6 \text { family members in T-cell activation, differentiation and } \\
\text { maturation (mouse studies) }\end{array}$ & -2.4165 & Mallya et al. (2006) [62] \\
\hline $\begin{array}{l}\text { BTRAPPIN-5 } \\
+\end{array}$ & $\begin{array}{l}\text { Multifunctional host-defense peptide with anti-proteolytic, anti-inflammatory and } \\
\text { anti-microbial activities. }\end{array}$ & -2.25014 & Kato et al. (2010) [63] \\
\hline SUSD2 ${ }^{+}$ & $\begin{array}{l}\text { Contributes to evasion of immune responses by induction of apoptosis in } \\
\text { activated T-cells }\end{array}$ & -2.24943 & Watson. (2011) [23] \\
\hline $\mathrm{KLRJ}^{+}$ & (see Table 3 on RAJ) & -2.04608 & Storset et al. (2003) [27] \\
\hline FCRLA $^{-}$ & Leading to inflammatory responses and antibody-mediated cellular cytotoxicity. & 7.21319 & Inozume et al. (2007) [64] \\
\hline $\mathrm{CXCL} 13^{-}$ & Chemokine B-lymphocyte chemoattractant. & 6.63854 & Legler et al. (1998) [65] \\
\hline DEFB5 $^{-}$ & $\begin{array}{l}\text { Bovine neutrophil } \beta \text {-defensins exert broad spectrum of antimicrobial activities } \\
\text { against several species that cause mastitis as S. aureus, E. coli, K. pneumoniae and } P \text {. } \\
\text { aeruginosa }\end{array}$ & 6.0118 & Alnakip et al. (2014) [66] \\
\hline BT. $53744^{-}$ & Development and differentiation of B-cells into plasma cells. & 6.01462 & $\begin{array}{l}\text { International Molecular Exchange } \\
\text { Consortium (2015) [67] }\end{array}$ \\
\hline TNFRSF13C & Mature B-cell survival. & 5.9961 & Thompson et al. (2001) [68] \\
\hline $\mathrm{CD} 79 \mathrm{~B}^{-}$ & $\begin{array}{l}\text { Initiation of the signal transduction cascade activated by the B-cell antigen } \\
\text { receptor complex which will lead to antigen presentation. }\end{array}$ & 5.81055 & $\begin{array}{l}\text { Luisiri et al. (1996) [69], Tseng et al. } \\
\text { (1997) [70], Pelanda et al. (2002) [71] }\end{array}$ \\
\hline SRCRB4D ${ }^{-}$ & Regulation of innate and adaptive immune responses. & 5.45381 & OMIM database (2004) [72] \\
\hline CD180 & Controls B-cell recognition and signaling of LPS. & 4.59918 & $\begin{array}{l}\text { NCBI Reference Sequence Database } \\
\text { (2008) [73] }\end{array}$ \\
\hline FCRL1 ${ }^{-}$ & Functions in B-cell activation and differentiation. & 4.43127 & $\begin{array}{l}\text { Gauld et al. (2002) [74], Harwoord et al. } \\
\text { (2010) [75] }\end{array}$ \\
\hline $\mathrm{CLEC} \mathrm{E}^{-}$ & $\begin{array}{l}\text { Induces secretion of inflammatory cytokines after binding of ligands (such as } \\
\text { damaged cells, funghi and microbacteria). }\end{array}$ & 4.4039 & Miyake et al. (2010) [76] \\
\hline $\mathrm{CXCR5}^{-}$ & Chemokine plays an essential role in B-cell migration. & 4.00308 & Sáez de Guinoa et al. (2011) [25] \\
\hline $\mathrm{CD}_{1} 9^{-}$ & Acts as a B-cell coreceptor in conjunction with CD21 and CD81. & 3.8374 & Van Zelm et al. (2006) [77] \\
\hline P2RY8 ${ }^{-}$ & Regulator of the immune response. & 4.05228 & Amisten et al. (2007) [78] \\
\hline $\mathrm{LTA}^{-}$ & $\begin{array}{l}\text { Mediates a large variety of inflammatory, immunostimulatory and antiviral } \\
\text { responses. }\end{array}$ & 3.70982 & $\begin{array}{l}\text { NCBI Reference Sequence Database } \\
\text { (2012) [79] }\end{array}$ \\
\hline $\mathrm{CXCR}^{-}$ & Receptor for SDF-1, has potent chemotactic activity for lymphocytes. & 3.67364 & Tamamis et al. (2014) [80] \\
\hline TLR10 & Role in pathogen recognition and activation of innate immunity. & 3.64532 & Lee et al. (2014) [81] \\
\hline $\mathrm{SPP}^{-}$ & $\begin{array}{l}\text { Chemotactic for many cell types including macrophages, dendritic cells and T } \\
\text { cells; it enhances B lymphocyte immunoglobulin production and proliferation. In } \\
\text { inflammatory situations it stimulates both pro- and anti-inflammatory processes. }\end{array}$ & 3.49813 & Wang et al. (2008) [82] \\
\hline $\mathrm{BANK}^{-}$ & Is expressed during development of B-lineage cells. & 3.34384 & Dymecki et al. (1992) [83] \\
\hline $\mathrm{FCRL}^{-}$ & Regulator of the immune system. & 3.32282 & Swainson et al. (2010) [84] \\
\hline $\mathrm{LTB}^{-}$ & $\begin{array}{l}\text { LTs are important for innate and adaptive immune responses by controlling the } \\
\text { expression of several adhesion molecules, other cytokines and chemokines }\end{array}$ & 2.50217 & Creus et al. (2012) [85] \\
\hline $\mathrm{DOK}^{-}$ & Negative regulator of JNK signaling in B-cells. & 3.02771 & Robson et al. (2004) [86] \\
\hline $\mathrm{KLRF}^{-}$ & & 3.00125 & Kuttruff et al. (2009) [31] \\
\hline
\end{tabular}


Table 4 Gene expression results for lleal Peyer's patches samples with fold change $>2$ (Continued)

\begin{tabular}{|c|c|c|c|}
\hline & $\begin{array}{l}\text { Activating lectin-like receptor expressed on NK-cells and stimulates their } \\
\text { cytotoxicity and cytokine release. }\end{array}$ & & \\
\hline FCER2 $^{-}$ & Transportation in antibody feedback regulation & 2.85172 & Kijimoto-Ochiai (2002) [87] \\
\hline FCAMR $^{-}$ & $\begin{array}{l}\text { is expressed constitutively on the majority of B-lymphocytes and macrophages; } \\
\text { FCAMR functions as a receptor for the FC fragment of IgA and IgM and binds IgA } \\
\text { and IgM with high affinity and mediates their endocytosis }\end{array}$ & 2.82211 & $\begin{array}{l}\text { Shibuya et al. (2000) [88], McDonald et } \\
\text { al. (2002) [89] }\end{array}$ \\
\hline CCL19- & $\begin{array}{l}\text { Antimicrobial gene; may play a role in normal lymphocyte recirculation and } \\
\text { homing. It also plays an important role in trafficking of T cells in thymus, and in } T \\
\text { cell and B cell migration to secondary lymphoid organs }\end{array}$ & 2.54095 & $\begin{array}{l}\text { National Center for Biotechnology } \\
\text { Information Gene (2014) [90] }\end{array}$ \\
\hline TNFSF8 $^{-}$ & Involved in cell differentiation, apoptosis and immune response & 2.43376 & Wei et al. (2011) [91] \\
\hline $\mathrm{SOCS}^{-}$ & Negative regulator of cytokine signaling. & 2.33913 & Krebs et al. (2011) [92] \\
\hline TIMD4 $^{-}$ & $\begin{array}{l}\text { Enhances the engulfment of apoptotic cells: involved in regulating T-cell } \\
\text { proliferation and lymphotoxin signaling. }\end{array}$ & 2.304 & Uniprot (2015) [93] \\
\hline $\mathrm{SIT}^{-}$ & Negatively regulates T-cell receptor mediated signaling in T-cells. & 2.28439 & Marie-Cardine et al. (1999) [94] \\
\hline $\mathrm{BDKRB1}^{-}$ & $\begin{array}{l}\text { Receptor binding leads to increase in the cytosolic calcium ion concentration, } \\
\text { resulting in chronic and acute inflammatory responses. }\end{array}$ & 2.26204 & $\begin{array}{l}\text { Talbot et al. (2012) [95], Enquist et al. } \\
\text { (2014) [96] }\end{array}$ \\
\hline AKAP5 $^{-}$ & $\begin{array}{l}\text { Is expressed in T-lymphocytes and may function to inhibit IL-2; IL-2 is part of the } \\
\text { body's natural responses to microbial infections. }\end{array}$ & 2.20946 & Schillace et al. (2002) [97] \\
\hline PGLYRP2 $^{-}$ & Recognizes peptidoglycan, a component of bacterial cell walls. & 2.19916 & Dziarski et al. (2010) [98] \\
\hline $\mathrm{CD}_{3} 7^{-}$ & T-cell and B-cell interactions. & 2.13192 & Knobeloch et al. (2000) [99] \\
\hline
\end{tabular}

were able to show suppression of immunity on different levels of the innate and adaptive immune response, indicating that E. coli O157:H7 can modulate this response in a wide variety of ways. The excretion patterns confirm our previous findings, as a first infection mounts a higher level of bacterial shedding during a shorter period of time compared to a re-infection. It might be mooted that there is a correlation between the higher level of infection and a more pronounced effect on the immune system. However, we hypothesize that the priming of the immune system by the first exposure is more important than the level of bacteria since a second infection with $E$. coli $\mathrm{O} 157: \mathrm{H} 7$ mostly results in a prolongued colonization, whereas for other pathogenic E. coli such as enterotoxigenic $E$. coli in pigs a complete protection occurs after a first infection.

Our data suggests that an infection with E. coli O157:H7 $\left(\mathrm{Stx}^{-}\right)$is capable of modulating the immune response causing dramatic decreases in CCL20. A similar trend was observed in a bacterial infection with Mycoplasma

Table 5 Duration of infection after primary or re-infection with NCTC12900 strain

\begin{tabular}{lll}
\hline Duration of infection & $\begin{array}{l}\text { Primary infection } \\
(n=32)\end{array}$ & $\begin{array}{l}\text { Re-infection } \\
(n=26)\end{array}$ \\
\hline $0-7$ days & 9 & 0 \\
$7-14$ days & 23 & 5 \\
$14-21$ days & 0 & 4 \\
$21-28$ days & 0 & 3 \\
$>28$ days & 0 & 14 \\
\hline
\end{tabular}

gallisepticum in chicken, where a down-regulation in mRNA expression of CCL20 as well as of $I L-1, I L-8$ and $I L-12 p 40$ genes was seen. These results indicate the importance of lymphocyte and monocyte chemotactic factors in development of disease, but also the fast occurrence of modulations of the host immune responses by bacteria [22].

Granulysin delivers granzymes into bacteria to kill diverse bacterial strains. In Escherichia coli, granzymes cleave electron transport chain complex I and oxidative stress defense proteins, generating reactive oxygen species (ROS) that rapidly kill bacteria [48]. An upregulation of granulysin is part of the adaptive immune response against bacterial infections.

A study of St John et al. [49] demonstrated downregulation of CXCL13 and CCL21 during an infection of draining lymph nodes by Salmonella typhimurium. The pathogen disrupts the lymph node architecture and cellular trafficking, which enhances its virulence and could serve as a mechanism of immune suppression used by pathogens that primarily target lymphoid tissue. In our study, we could not observe a significant downregulation of CXCL13 nor CCL21 altough the bacterium is in close contact to lymphoid dense tissue in the RAJ and the ileum.

We observed a downregulation of IL17REL, a gene which is important for a fast inflammatory response. The cells of the innate immune system are the first line of defense against pathogen and their cytokines govern the differentiation of $\mathrm{T}$ - helper cells. Their pattern-recognition receptors, which are not specific for any particular 
epitope, allow them to respond to a wide variety of microbial invaders by producing cytokines that activate T-cells of the adaptive immune system. T-helper 17 cells produce IL17 and this is particularly important for immunity at epithelial and mucosal surfaces, as indicated by the pattern of expression of their chemokine receptors and effector cytokines. Several pathogens, like gram-positive Propionibacterium acnes and gram-negative Citrobacter rodentium, induce mainly Th17 responses [50]. Furthermore, Luo et al. [51] have shown that F4 fimbriae of ETEC can elicit an IL17 response in piglets, suggesting a role in protection of the host against ETEC infection.

A downregulation of $I L 21 R$ might play a role in the persistence of colonization during the primary E. coli O157:H7-infection and re-infection of the host, since the IL-21-IL-21R pathway is important in the development of immune responses, as abnormal signaling through the IL-21R//c/JAK3/STAT3 pathway leads to defective humoral immune responses to both T-dependent and Tindependent antigens and impairs the establishment of long-lasting B-cell memory [52]. A bacterial infection can elicit IgM memory B-cells which requires T celldependent and IL-21R signaling. The study of Yates et al. [53] demonstrates that T cell-dependent IgM memory $B$ cells can be elicited at high frequency and can play an important role in maintaining long-term immunity during bacterial infection.

In the RAJ, we could observe the downregulation of $M A R C O$, a receptor that can bind Gram-negative bacteria and is only found on macrophages of the marginal zone of the spleen and lymph nodes [32]. Pinheiro da Silva et al. [54] have shown that E. coli are capable of hijacking inhibitory ITAMs leading to a decrease in MARCO-mediated phagocytosis. This observation is indicating a decrease in antibacterial protection of the host at the primary site of EHEC infection.

Due to biosafety reasons and limitations on housing facilities we performed this experiment using an E. coli O157:H7 $\left(\mathrm{Stx}^{-}\right)$strain. Although this is not the exact same strain as the strains found during natural EHECinfections, this study may be seen as a first step to investigate the immunomodulating capacities of $E$. coli O157:H7 strains in cattle using RNA-Seq. We believe that this study is a valuable contribution to the current knowledge on immune suppression in the bovine host and this study is congruent with previous findings showing that also other bacterial factors apart from Stx can play a role in immune suppression.

A limitation of our study is that most information from gene function databases is derived from studies that are not performed in cattle but in human and mice, therefore we have to take into consideration speciesspecific differences which we unfortunately can not control. This study is important since it is the first study using the highly-accurate and sensitive RNA-Seq technique to study the effect of EHEC on the cattle immune responses. These insights are crucial to better understand EHEC colonization and shedding within herds and our data could contribute to effective measures to control EHEC colonization in ruminants, thereby reducing zoonotic food-borne infections in humans.

\section{Conclusions}

We can conclude that the main effect on the transcriptome was immune suppression by $E$. coli $\mathrm{O} 157: \mathrm{H} 7$ due to an upregulation of immune suppressive effects (7/12 genes) or a downregulation of immunostimulatory effects (69/94 genes). Furthermore, the changes in gene expression were remarkably higher in the ileal Peyer's patches (1159 genes) than in the RAJ (15 genes) during a primary infection. This effect was less obvious after the reinfection (17 and 10 genes, respectively). The data might indicate that a primary infection promotes a re-infection with EHEC by suppressing the immune function.

\section{Abbreviations}

CT-SMAC: Cefiximin Tellurite - Sorbitol MacConkey agar; DC's: Denditic cells; E. coli: Escherichia coli; EHEC: Enterohaemorrhagic Escherichia coli; EPEC: Enteropathogenic Escherichia coli; Esp: E. coli secreted protein; FDR: False discovery rate; GO: Gene ontology; IMS: Immunomagnetic separation; IPA: Ingenuity pathway analysis; LB: Luria Bertani broth; LEE: Locus of enterocyte effacement; LPS: Lipopolysaccharide; MHC: Major

histocompatibility complex; mRNA: Messenger RNA; NK-cells: Natural killer cells; PBS: Phosphate buffered saline; RAJ: Recto-anal junction; RNA-Seq: RNAsequencing; ROS: Reactive oxygen species; Stx: Shiga toxin; T3SS: Type III secretion system; Th: T-helper; Tir: Translocated intimin receptor; TLR: Toll-like receptor; UPEC: Uropathogenic Escherichia coli

\section{Acknowledgements}

We would like to thank S. Brabant and R. Cooman for their technical assistance and help with handling of the animals.

\section{Funding}

We would like to thank the Belgian Federal Public Service of Health, Food Chain Safety and Environment for the financial support (RF10/6233).

\section{Availability of data and materials}

The datasets supporting the conclusions of this article are included within the article and its additional files. The supplementary data files can be accessed on ArrayExpress via accession number E-MTAB-4533.

\section{Authors' contributions}

EK: carried out experimental design and coordination, data analysis, drafted the manuscript. JR: helped with animal handling and sample collection and revised the manuscript in a critical way. RWL: carried out the RNA-Seq study, collected raw data and performed statistical analysis, completed and revised the manuscript. DV and EC: conceived and designed experimental study, made critical revisions on the manuscript. All authors read and approved the final manuscript.

Competing interests

The authors declare that they have no competing interests.

Consent for publication

This manuscript does not contain data involving human participants and therefore no consent for participation was needed. 


\section{Ethics approval}

All experimental and animal management procedures were undertaken in accordance to the requirements of the animal care and ethics committee of the Faculty of Veterinary Medicine, Ghent University, Belgium (EC2011/082).

\section{Author details}

'Laboratory of Immunology, Faculty of Veterinary Medicine, Ghent University, Salisburylaan 133, 9820 Merelbeke, Belgium. ${ }^{2}$ USDA-ARS, Bovine Functional Genomics Laboratory, Beltsville, MD, USA. ${ }^{3}$ Laboratory of Immunology and Animal Biotechnology, Faculty of Bioscience Engineering, Ghent University, Coupure Links 653, 9000 Ghent, Belgium.

Received: 21 June 2016 Accepted: 5 December 2016 Published online: 21 December 2016

\section{References}

1. Tutenel A, Pierard D, Uradzinski J, Jozwik E, Pastuszczak M, Van Hende J, Uyttendaele M, Debevere J, Cheasty T, Van Hoof J, De Zutter L. Isolation and characterization of enterohaemorrhagic Escherichia coli 0157:1 H7 from cattle in Belgium and Poland. Epidemiol Infect. 2002;129(1):41-7.

2. Caprioli A, Morabito S, Brugère H, Oswald E. Enterohaemorrhagic Escherichia coli: emerging issues on virulence and modes of transmission. Vet Res. 2005;36:289-311

3. Vilte DA, Larzabal M, Garbaccio S, Gammella M, Rabinovitz BC, Elizondo AM, Cantet RJC, Delgado F, Meikle V, Cataldi A, Mercado EC. Reduced faecal shedding of Escherichia coli $\mathrm{O} 157: \mathrm{H7}$ in cattle following systemic vaccination with gamma-intimin C(2)(8)(0) and EspB proteins. Vaccine. 2011; 29(23):3962-8

4. Stevens MP, van Diemen PM, Dziva F, Jones PW, Wallis TS. Options for the control of enterohaemorrhagic Escherichia coli in ruminants. Microbiology. 2002;148:3767-78.

5. Joris M-A. Prevalence, characterization and long-term follow up of Enterohemorrhagic Escherichia coli and type III secretion system specific antibodies in cattle. Ghent: Ghent University; 2012.

6. Joris MA, Verstraete K, De Reu K, De Zutter L. Longitudinal follow-up of the persistence and dissemination of EHEC on cattle farms in Belgium. Foodborne Pathog Dis. 2013;10(4):295-301.

7. Rahn K, Renwick SA, Johnson RP, Wilson JB, Clarke RC, Alves D, McEwen S, Lior H, Spika J. Persistence of Escherichia coli 0157 : H7 in dairy cattle and the dairy farm environment. Epidemiol Infect. 1997;119(2):251-9.

8. Hoffman M, Menge C, Casey T, Laegreid W, Bosworth B, Dean-Nystrom E. Bovine immune response to shiga-toxigenic Escherichia coli 0157:H7. Clin Vaccine Immunol. 2006;13(12):1322-7.

9. Joris M, Vanrompay D, Verstraete K, De Reu K, De Zutter L, Cox E. Use of antibody responses against Locus of Enterocyte Effacement (LEE)-encoded antigens to monitor Enterohemorrhagic Escherichia coli Infections on cattle farms. Appl Environ Microbiol. 2013;79(12):3677-83.

10. Naylor SW, Low JC, Besser TE, Mahajan A, Gunn GJ, Pearce MC, McKendrick IJ, Smith DGE, Gally DL. Lymphoid follicle-dense mucosa at the terminal rectum is the principal site of colonization of enterohemorrhagic Escherichia coli 0157: H7 in the bovine host. Infect Immun. 2003;71(3):1505-12.

11. Menge C, Stamm I, Blessenohl M, Wieler LH, Baljer G. Verotoxin 1 from Escherichia coli Affects Gb3/CD77+ Bovine Lymphocytes Independent of Interleukin-2, Tumor Necrosis Factor-a, and Interferon-a. Exp Biol Med. 2003; 228(4):377-86.

12. Yasuda $M$, Jenne $C N$, Kennedy $L$, Reynolds J. The sheep and cattle Peyer's patch as a site of B-cell development. Vet Res. 2006;37:401-15.

13. Hauf N, Chakraborty T. Suppression of NFB Activation and Proinflammatory cytokine expression by shiga toxin-producing Escherichia coli. J Immunol. 2003;170:2074-82.

14. Stevens M, Frankel $\mathrm{G}$. The locus of enterocyte effacement and associated virulence factors of Enterohemorrhagic Escherichia coli. In: Enterohemorrhagic Escherichia coli. 2015. p. 97-130.

15. Corbishley A, Ahmad NI, Hughes K, Hutchings MR, McAteer SP, Connelley TK, Brown H, Gally DL, McNeilly TN. Strain-dependent cellular immune responses in cattle following Escherichia coli O157:H7 colonization. Infect Immun. 2014;82(12):5117-31.

16. Dibb-Fuller MP, Best A, Stagg DA, Cooley WA, Woodward MJ. An in-vitro model for studying the interactions of Escherichia coli O157:H7 and other enteropathogens with bovine primary cell cultures. J Med Microbiol. 2001;50:759-69.
17. Kieckens E, Rybarczyk J, De Zutter L, Duchateau L, Vanrompay D, Cox E. Clearance of Escherichia coli 0157:H7 Infection in Calves by Rectal Administration of Bovine Lactoferrin. Appl Environ Microbiol. 2015;81(5):1644-51.

18. Vande Walle K, Yekta MA, Verdonck F, De Zutter L, Cox E. Rectal inoculation of sheep with $\mathrm{E}$. coli $0157: \mathrm{H7}$ results in persistent infection in the absence of a protective immune response. Vet Microbiol. 2011;147(3-4):376-82.

19. Trapnell C, Pachter L, Salzberg SL. TopHat: discovering splice junctions with RNA-Seq. Bioinformatics. 2009;25(9):1105-11.

20. Anders $S$, Huber W. Differential expression analysis for sequence count data. Genome Biol. 2010;11(10):R106.

21. Li RW, Schroeder SG. Cytoskeleton remodeling and alterations in smooth muscle contractility in the bovine jejunum during nematode infection. Funct Integr Genomics. 2012;12(1):35-44.

22. Mohammed J, Frasca SJ, Cecchini K, Rood D, Nyaoke AC, Geary SJ, Silbart LK. Chemokine and cytokine gene expression profiles in chickens inoculated with Mycoplasma gallisepticum strains Rlow or GT5. Vaccine. 2007;25(51): 8611-21.

23. Watson A, Gubbels JAA, Egland KA. Sushi domain containing 2 (SUSD2): A plasma membrane protein on breast cancer cells that interacts with galectin-1. In: Proc. 102nd Annu. Meet. Am. Assoc. Cancer Res. 2011 Apr 2-6; Orlando, FL. Philadelphia AACR. Cancer Res. 2011;71(8 Suppl) Abstract nr 3054.

24. Meyers JH, Sabatos CA, Chakravarti S, Kuchroo VK. The TIM gene family regulates autoimmune and allergic diseases. Trends Mol Med. 2005;11(8):362-9.

25. Sáez de Guinoa J, Barrio L, Mellado M, Carrasco YR. CXCL13/CXCR5 signaling enhances BCR-triggered B-cell activation by shaping cell dynamics. Blood. 2011;118(6):1560-9.

26. Wu B, Jin M, Zhang $Y$, Wei T, Bai Z. Evolution of the IL17 receptor family in chordates: a new subfamily IL17REL. Immunogenetics. 2011;63:835-45.

27. Storset AK, Slettedal IÖ, Williams JL, Law A, Dissen E. Natural killer cell receptors in cattle: a bovine killer cell immunoglobulin-like receptor multigene family contains members with divergent signaling motifs. Eur J Immunol. 2003:33(4):980-90.

28. Poggi A, Zocchi MR. NK cell autoreactivity and autoimmune diseases. Front Immunol. 2014:5:27.

29. André $P$, Castriconi R, Espéli M, Anfossi N, Juarez T, Hue S, Conway H, Romagné F, Dondero A, Nanni M, Caillat-Zucman S, Raulet DH, Bottino C, Vivier E, Moretta A, Paul P. Comparative analysis of human NK cell activation induced by NKG2D and natural cytotoxicity receptors. Eur J Immunol. 2004; 34(4):961-71.

30. Karimi M, Cao TM, Baker JA, Verneris MR, Soares L, Negrin RS. Silencing human NKG2D, DAP10, and DAP12 reduces cytotoxicity of activated CD8 T cells and NK cells. J Immunol. 2005;175:7819-28.

31. Kuttruff S, Koch S, Kelp A, Pawelec G, Rammensee HG, Steinle A. NKp80 defines and stimulates a reactive subset of CD8 T cells. Blood. 2009;113(2):358-69.

32. Elomaa O, Sankala M, Pikkarainen T, Bergmann U, Tuuttila A, RaatikainenAhokas A, Sariola H, Tryggvason K. Structure of the human macrophage MARCO receptor and characterization of its bacteria-binding region. J Biol Chem. 1998;273:4530-8.

33. Rehli M, Krause SW, Andreesen R. The membrane-bound Ectopeptidase CPM as a marker of macrophage maturation in vitro and in vivo. Adv Exp Med Biol. 2002:477:205-16.

34. McKnight AJ, Gordon S. The EGF-TM7 family: unusual structures at the leukocyte surface. J Leukoc Biol. 1998;63(3):271-80.

35. Rex S, Kraemer S, Grieb G, Emontzpohl C, Soppert J, Goetzenich A, Rossaint $\mathrm{R}$, Bernhagen J, Stoppe C. The role of macrophage migration inhibitory factor in critical illness. Mini Rev Med Chem. 2014;14(14):1116-24.

36. Anderson MW, Zhao S, Ai WZ, Tibshirani R, Levy R, Lossos IS, Natkunam Y. C-C chemokine receptor 1 expression in human hematolymphoid neoplasia. Am J Clin Pathol. 2010;133(3):473-83.

37. Whitney G, Wang S, Chang H, Cheng KY, Lu P, Zhou XD, Yang WP, McKinnon M, Longphre M. A new siglec family member, siglec-10, is expressed in cells of the immune system and has signaling properties similar to CD33. Eur J Biochem. 2001;268(23):6083-96.

38. NaserEddin A, Shamriz O, Keller B, Alzyoud RM, Unger S, Fisch P, Prus E, Berkun Y, Diana Averbuch D, Shaag A, Wahadneh AM, Conley ME, Warnatz K, Elpeleg O, Stepensky P. Enteroviral Infection in a Patient with BLNK Adaptor Protein Deficiency. J Clin Immunol. 2015;35(4):356-60.

39. White JR, Imburgia C, Dul E, Appelbaum E, O'Donnell K, O'Shannessy DJ, Brawner M, Fornwald J, Adamou J, Elshourbagy NA, Kaiser K, Foley JJ, Schmidt DB, Johanson K, Macphee C, Moores K, McNulty D, Scott GF, Schleimer RP, Sarau HM. Cloning and functional characterization of a novel 
human CC chemokine that binds to the CCR3 receptor and activates human eosinophils. J Leukoc Biol. 1997;62(5):667-75.

40. Nordenfelt $\mathrm{P}$, Tapper $\mathrm{H}$. Phagosome dynamics during phagocytosis by neutrophils. J Leukoc Biol. 2001;268(23):6083-96.

41. Quintrell N, Lebo R, Varmus H, Bishop JM, Pettenati MJ, Le Beau MM, Diaz $\mathrm{MO}$, Rowley JD. Identification of a human gene ( $\mathrm{HCK}$ ) that encodes a protein-tyrosine kinase and is expressed in hemopoietic cells. Mol Cell Biol. 1987;7(6):2267-75.

42. Hwang SJ, Ballantyne CM, Sharrett AR, Smith LC, Davis CE, Gotto AMJ, Boerwinkle E. Circulating adhesion molecules VCAM-1, ICAM-1, and Eselectin in carotid atherosclerosis and incident coronary heart disease cases: the Atherosclerosis Risk In Communities (ARIC) study. Circulation. 1997; 96(12):4219-25.

43. Janeway CA, Travers P, Walport M, Shlomchik MJ. Immunobiology. Garl Sci Publ. 2005:462-470.

44. Schmid-Hempel P. Immune defence, parasite evasion strategies and their relevance for 'macroscopic phenomena' such as virulence. Philos Trans $\mathrm{R}$ Soc L B Biol Sci. 2009;364(1513):85-98.

45. Croxen MA, Finlay BB. Molecular mechanisms of Escherichia coli pathogenicity. Nat Rev Microbiol. 2010;8(1):26-38.

46. Hunstad DA, Justice SS. Intracellular lifestyles and immune evasion strategies of uropathogenic Escherichia coli. Annu Rev Microbiol. 2010;64:203-21.

47. Li J, Hovde CJ. Expression profiles of bovine genes in the rectoanal junction mucosa during colonization with Escherichia coli O157:H7. Appl Environ Microbiol. 2007;73(7):2380-5.

48. Walch M, Dotiwala F, Mulik S, Thiery J, Kirchhausen T, Clayberger C, Krensky AM, Martinvalet D, Lieberman J. Cytotoxic cells kill intracellular bacteria through granulysin-mediated. Cell Press. 2014;157(6):1309-23.

49. John ALS, Abraham SN. Salmonella disrupts lymph node architecture by TLR4-mediated suppression of homeostatic chemokines. Nat Med. 2009; 15(11):1259-65.

50. Miossec P, Korn T, Kuchroo VK. Interleukin-17 and Type 17 Helper T Cells. N Engl J Med. 2009;361(9):888-98.

51. Luo Y, Van Nguyen U, de la Fe Rodriguez PY, Devriendt B, Cox E. F4+ ETEC infection and oral immunization with F4 fimbriae elicits an IL-17-dominated immune response. Vet Res. 2015;46(1):121

52. Desjardins M, Mazer BD. B-cell memory and primary immune deficiencies: interleukin-21 related defects. Curr Opin Allergy Clin Immunol. 2013;13(6): 639-45.

53. Yates JL, Racine R, McBride KM, Kinslow GM. T cell-dependent IgM memory $\mathrm{B}$ cells generated during bacterial infection are required for $\mathrm{lgG}$ responses to antigen challenge. J Immunol. 2013;191(3):1240-9.

54. Pinheiro da Silva F, Aloulou M, Benhamou M, Monteiro RC. Inhibitory ITAMs: a matter of life and death. Trends Immunol. 2008;29(8):366-73.

55. Wu J, Nilsson A, Jönsson BA, Stenstad H, Agace W, Cheng Y, Duan RD. Intestinal alkaline sphingomyelinase hydrolyses and inactivates plateletactivating factor by a phospholipase C activity. Biochem J. 2006;394:299-308.

56. LeBrasseur N. Fight infection with oxidation. J Cell Biol. 2006;4:518.

57. Vilches C, Parham P. KIR: diverse, rapidly evolving receptors of innate and adaptive immunity. Annu Rev Immunol. 2002;20:217-51.

58. European Bioinformatics Institute. Eggnog. 2015.

59. Bouchard B, Ormandy CJ, Di Santo JP, Kelly PA. Immune system development and function in prolactin receptor-deficient mice. J Immunol. 1999;163(2):576-82.

60. Lee RC, Walters JA, Reyland ME, Anderson SM. Constitutive activation of the prolactin receptor results in the induction of growth factor-independent proliferation and constitutive activation of signaling molecules. J Biol Chem. 1999;274(15):10024-34.

61. Amaral ME, Cunha DA, Anhê GF, Ueno M, Carneiro EM, Velloso LA, Bordin S, Boschero AC. Participation of prolactin receptors and phosphatidylinositol 3kinase and MAP kinase pathways in the increase in pancreatic islet mass and sensitivity to glucose during pregnancy. J Endocrinol. 2004;183(3):469-76.

62. Mallya M, Campbell RD, Aguado B. Characterization of the five novel Ly- 6 superfamily members encoded in the MHC, and detection of cells expressing their potential ligands. Protein Sci. 2006;15(10):2244-56.

63. Kato A, Rooney AP, Furutani Y, Hirose S. Evolution of trappin genes in mammals. BMC Evol Biol. 2010;10:31.

64. Inozume T, Mitsui H, Okamoto T, Matsuzaki Y, Kawakami Y, Shibagaki N, Shimada S. Dendritic cells transduced with autoantigen FCRLA induce cytotoxic lymphocytes and vaccinate against murine Bcell lymphoma. J Invest Dermatol. 2007;127(12):2818-22.
65. Legler DF, Loetscher M, Roos RS, Clark-Lewis I, Baggiolini M, Moser B. B cellattracting chemokine 1, a human CXC chemokine expressed in lymphoid tissues, selectively attracts B lymphocytes via BLR1/CXCR5. J Exp Med. 1998; 187(4):655-60.

66. Alnakip ME, Quintela-Baluja M, Böhme K, Fernández-No I, Caamaño-Antelo S, Calo-Mata P, Barros-Velázquez J. The Immunology of Mammary Gland of Dairy Ruminants between Healthy and Inflammatory Conditions. J Vet Med. 2014;2014:659801.

67. International Molecular Exchange Consortium, 2015.

68. Thompson JS, Bixler SA, Qian F, Vora K, Scott ML, Cachero TG, Hession C, Schneider P, Sizing ID, Mullen C, Strauch K, Zafari M, Benjamin CD, Tschopp J, Browning JL, Ambrose C. BAFF-R, a newly identified TNF receptor that specifically interacts with BAFF. Science. 2001;293(5537):2108-11.

69. Luisiri P, Lee YJ, Eisfelder BJ, Clark MR. Cooperativity and segregation of function within the lg-alpha/beta heterodimer of the B cell antigen receptor complex. J Biol Chem. 1996;271(9):5158-63.

70. Tseng J, Eisfelder BJ, Clark MR. B-cell antigen receptorinduced apoptosis requires both Ig alpha and lg beta. Blood. 1997;89(5):1513-20.

71. Pelanda R, Braun U, Hobeika E, Nussenzweig MC, Reth M. B cell progenitors are arrested in maturation but have intact VDJ recombination in the absence of Ig-alpha and Ig-beta. J Immunol. 2002;169(2):865-72.

72. Online Mendelian Inheritance in Man, SSC4D scavenger receptor cysteine rich family, 4 domains. 2004

73. Reference Sequence Database NCBI. CD180 CD180 molecule. 2008.

74. Gauld SB, Dal Porto JM, Cambier JC. B cell antigen receptor signaling: roles in cell development and disease. Science. 2002;296:1641-2.

75. Harwood NE, Batista FD. Early events in B cell activation. Annu Rev Immunol. 2010;28:185-210.

76. Miyake $\mathrm{Y}$, Ishikawa E, Ishikawa T, Yamasaki S. Self and nonself recognition through C-type lectin receptor, Mincle. Self Nonself. 2010;1(4):310-3.

77. van Zelm MC, Reisli I, van der Burg M, Castaño D, van Noesel CJ, van Tol MJ, Woellner C, Grimbacher B, Patiño PJ, van Dongen JJ, Franco JL. An antibody-deficiency syndrome due to mutations in the CD19 gene. N Engl J Med. 2006;354(18):1901-12.

78. Amisten S, Melander O, Wihlborg AK, Berglund G, Erlinge D. Increased risk of acute myocardial infarction and elevated levels of $\mathrm{C}$-reactive protein in carriers of the Thr-87 variant of the ATP receptor P2Y11. Eur Heart J. 2007;28(1):13-8.

79. NCBI Reference Sequence Database, LTA. 2012.

80. Tamamis P, Floudas C. Elucidating a Key Component of Cancer Metastasis: CXCL12 (SDF-1a) Binding to CXCR4. J Chem Inf Model. 2014:54(4):1174-88.

81. Lee SM, Kok KH, Jaume M, Cheung TK, Yip TF, Lai JC, Guan Y, Webster RG, Jin DY, Peiris JS. Toll-like receptor 10 is involved in induction of innate immune responses to influenza virus infection. Proc Natl Acad Sci U S A. 2014;11(10):3793-8.

82. Wang KX, Denhardt DT. Osteopontin: role in immune regulation and stress responses. Cytokine Growth Factor Rev. 2008;19(5-6):333-45.

83. Dymecki SM, Zwollo P, Zeller K, Kuhajda P, Desiderio SV. tructure and developmental regulation of the B-lymphoid tyrosine kinase gene blk. J Biol Chem. 1992;267(7):4815-23.

84. Swainson LA, Mold JE, Bajpai UD, McCune JM. Expression of the autoimmune susceptibility gene FcRL3 on human regulatory T cells is associated with dysfunction and high levels of programmed cell death-1. J Immunol. 2010;184(7):3639-47.

85. Creus KK, De Paepe B, Weis J, De Bleecker JL. The multifaceted character of lymphotoxin $\beta$ in inflammatory myopathies and muscular dystrophies. Neuromuscul Disord. 2012;22(8):712-9.

86. Robson JD, Davidson D, Veillette A. Inhibition of the Jun Nterminal protein kinase pathway by SHIP-1, a lipid phosphatase that interacts with the adaptor molecule Dok-3. Mol Cell Biol. 2004;24(6):2332-43.

87. Kijimoto-Ochiai S. CD23 (the low-affinity IgE receptor) as a C-type lectin: a multidomain and multifunctional molecule. Cell Mol Life Sci. 2002;59(4):648-64.

88. Shibuya A, Sakamoto N, Shimizu Y, Shibuya K, Osawa M, Hiroyama T, Eyre HJ, Sutherland GR, Endo Y, Fujita T, Miyabayashi T, Sakano S, Tsuji T, Nakayama E, Phillips JH, Lanier LL, Nakauchi H. Fc alpha/mu receptor mediates endocytosis of IgM-coated microbes. Nat Immunol. 2000;1 (5):441-6.

89. McDonald KJ, Cameron AJ, Allen JM, Jardine AG. Expression of Fc alpha/mu receptor by human mesangial cells: a candidate receptor for immune complex deposition in IgA nephropathy. Biochem Biophys Res Commun. 2002;290(1):438-42.

90. National Center for Biotechnology Information Gene. CCL19 chemokine (CC motif) ligand 19 [ Homo sapiens (human). 2014. 
91. Wei S, Niu J, Zhao H, Liu Z, Wang L, Han Y, Chen W, Amos C, Rafnar T, Sulem P, Stefansson K, Landi M, Caporaso N, Albanes D, Thun M, McKay J, Brennan P, Wang Y, Houlston R, Spitz M, Wei Q. Association of a novel functional promoter variant (rs2075533 C>T) in the apoptosis gene TNFSF8 with risk of lung cancer-a finding from Texas lung cancer genome-wide association study. Carcinogenesis. 2011;32(4):507-15.

92. Krebs D, Hilton D. SOCS proteins: negative regulators of cytokine signaling Stem Cells. 2001;19(5):378-87.

93. UniProt. T-cell immunoglobulin and mucin domain-containing protein 4: by similarity. 2015.

94. Marie-Cardine A, Kirchgessner H, Bruyns E, Shevchenko A, Mann M, Autschbach F, Ratnofsky S, Meuer S, Schraven B. SHP2-interacting transmembrane adaptor protein (SIT), a novel disulfide-linked dimer regulating human T cell activation. J Exp Med. 1999;189(8):1181-94.

95. Talbot S, De Brito GH, Saint-Denis J, Couture R. Activation of kinin B1 receptor evokes hyperthermia through a vagal sensory mechanism in the rat. J Neuroinflammation. 2012;13(9):214.

96. Enquist J, Sandén C, Skröder C, Mathis SA, Leeb-Lundberg LM. Kininstimulated $B 1$ receptor signaling depends on receptor endocytosis whereas B2 receptor signaling does not. Neurochem Res. 2014;39(6):1037-47.

97. Schillace RV, Andrews SF, Liberty GA, Davey MP, Carr DW. Identification and characterization of myeloid translocation gene $16 \mathrm{~b}$ as a novel a kinase anchoring protein in T lymphocytes. J Immunol. 2002;168(4):1590-9.

98. Dziarski R, Gupta D. Review: Mammalian peptidoglycan recognition proteins (PGRPs) in innate immunity. Innate Immun. 2010;16(3):168-74.

99. Knobeloch KP, Wright MD, Ochsenbein AF, Liesenfeld O, Löhler J, Zinkernagel RM, Horak I, Orinska Z. Targeted inactivation of the tetraspanin CD37 impairs T-cell-dependent B-cell response under suboptimal costimulatory conditions. Mol Cell Biol. 2000;20(15):5363-9.

\section{Submit your next manuscript to BioMed Central and we will help you at every step:}

- We accept pre-submission inquiries

- Our selector tool helps you to find the most relevant journal

- We provide round the clock customer support

- Convenient online submission

- Thorough peer review

- Inclusion in PubMed and all major indexing services

- Maximum visibility for your research

Submit your manuscript at www.biomedcentral.com/submit

) Biomed Central 